\title{
Effect of Sowing Density and Sowing Method on the Productivity of Sesame (Sesamum Indicum L)
}

Gore Bi Boh Nestor ${ }^{*}$, Yao kouakou Abessika Georges, Gbotto Ahou Anique, Kadio Gnigouan Anzara, Yao Koffi Gédéon, Akaffou Doffou sélastique

Université Jean Lorougnon Guede

DOI: $10.36347 /$ sjavs.2020.v07i02.001

| Received: 04.02.2020 | Accepted: 11.02.2020 | Published: 16.02.2020

*Corresponding author: Gore Bi Boh Nestor

Abstract

Original Research Article

In a rural environment, the decrease of sesame (Sesamum indicum L) production is the result of suitable growing system absence mainly sowing density and sowing method. Thus, to improve production of these crops, some investigations were undertaken on experimental site of University of Jean Lorougnon Guède. In order to reach these objective two sowings methods (flat soil and mound soil) were tested in random design with three repetitions. Also, inside of each sowing method three sowing densities were tested mainly low density, medium density and high density. It results from statistical analysis that the values of yield and its components were recorded on flat soil with low density.

Keywords: Sesamum indicum, sowing density, sowing method, food security.

Copyright @ 2020: This is an open-access article distributed under the terms of the Creative Commons Attribution license which permits unrestricted use, distribution, and reproduction in any medium for non-commercial use (NonCommercial, or CC-BY-NC) provided the original author and source are credited.

\section{INTRODUCTION}

Farming sector provides essential of food for human being and animals. Indeed, it takes up two thirds of world population and constitutes a main source of income and job for the local community [1]. In Africa, food security remains the main objective to reach by government [2]. In this context, agricultural policy of government must be turn towards the crops diversification. Thus, Sesamum indicum L owing to it ease adaptation in breeding ground and it request on the market could constituted an opportunity for farmers [3]. For that purpose, a large area is done the groundwork by farmers to increase the production of sesame on Asian and Africa. In spite of efforts made by farmers, the production of this plant is still very low by hectare. According to Haruna et Abiniki [4] the yield per hectare exceeds rarely $500 \mathrm{~kg} / \mathrm{ha}$. In Côte d'Ivoire, production of sesame is well under this value. In ivorian territory, sesame breeding is essentially concentrated in bafing region clearly in Touba. In this locality, the traditional practice better absence of the control of the growing system particularly sowing density and sowing methods are justified the level of production of farmers. The sowing density plays a cardinal role in the determination of crops yield [5]. Indeed, when the density is under or over the optimum density that lead to an intra specific competition between crops to share nutriments in soil [6]. Thus, that will result to a production decrease. In this condition, determination of optimum density for each variety becomes vital. However, to increase and keep the production of sesame optimum density must be associated with a correct sowing method. The current study is realized in this context to improve crop production and the income of household rural area. Specifiquely, it will be about study effect of sowing density and sowing method on the productivity of sesame.

\section{MATERIAL AND MÉTHODS Study site}

Experimental were conducted on university Jean Lorougnon Guédé (latitude : 06 $533^{\prime} 56^{\prime \prime} \mathrm{N}$ and longitude : $06^{\circ} 26^{\prime} 30^{\prime \prime} \mathrm{W}$ ) located in Daloa[7].

\section{MATERIAL AND METHODS}

Experimental material biology was constituted with 756 plants for two sowing methods (sowing on flat soil and on mound). Those plants come from white seed of S. indicum (Figure 5).

\section{Expérimental design and treatment}

Field experiences took place on an area measured $12 \times 7 \mathrm{~m}$. After weeding, the plots were divided into two parts according to sowing methods: sowing on flat soil and sowing on mound. Separated with $2 \mathrm{~m}$ each one of plots was divided into three 
blocks. Inside of each block three elementary plots were step up corresponding to three densities: Low density, medium density and high density. In practice, plots with low densities comprised 24 sowing points with $30 \mathrm{~cm}$ apart on lines and $20 \mathrm{~cm}$ apart between lines. Concerning medium density plots, they comprised 36 sowing points with $20 \mathrm{~cm}$ apart on lines and $20 \mathrm{~cm}$ apart between lines. The highest density comprised 66 plants respecting $10 \mathrm{~cm}$ apart on lines and $20 \mathrm{~cm}$ apart between lines.

\section{Cultural practice}

Sowings were realized in December 2017. After sowing, plants were watered each three days untill the crops maturity. Watering was done each afternoon. At seedling stage, vigourless plants were removed per hole in order to maintain only one. Any fertilizer was used during trial. Three treatments of insecticide "Décis fort" were applied to protect plants against insect pests. A fungicide was also used to protect against crops diseases. Two weeding treatments were realized during trial to prevent weeds competition. The harvest started 18 April 2018 with crops having capsules colored yellow.

\section{DATA COLLECTED}

Data collected, have concerned six vegetatifs, four biomass and four production parameters. Vegetatifs are made up of ramifications number (RN), ramification number bearing fruits (RNF), ramification number without fruits (RNWF), diameter at collar ((DC), plant stem length (PSL), number of dead plants (NDP). The four biomasses are made up of dry leaves biomass (DLB), dry capsules biomass (DCB), dry stems biomass (DSB) and dry roots biomass (DRB). Production parameters have concerned date of first flower emergenced (DFFE), date of first capsule emergenced (DFCE), number of capsules per plant (NCP), weight of seed per density (WS).

\section{STATISTICAL ANALYSIS}

Analysis started by sowing methods comparison. When a significant difference is observed between the both methods, the one which records a better value of parameters has been chosen to continue analysis. Data relating to this sowing method have allowed to test block effect. Two scenarios are able to be presented from this test. In a first case, effect of block can be absent. In this condition, before realizing the following analysis, data from all blocks will be gathered. But when a block effect is noted, it is corrected before continue analysis. After, the two steps an one way analysis of variance is realized to test effect of sowing density on sesame productivity parameters. For each one of variables which have been significantly affected by production factor multiples comparison are done by realizing $p p d s$ test $(P \leq 0,05)$. This test allows identifying parameters which differ significantly to others. All analysis have been made with Statistica solfware version 7.1.

\section{RESULTS AND DISCUSSION \\ Results}

\section{Effect of sowing density on vegetatif parameters of Sesamum indicum}

Except of stem length and number of dead plants other parameters have been influenced by sowing density $(P \leq 0.05)$. Thus, plants coming from a low density produced several ramifications (10.80 \pm 3.12$)$ than the two others. It is also with the same density ramifications bearing more fruits have been observed (8.70 \pm 6.70$)$. Plants with less ramifications without capsules $(2.10 \pm 2.19)$ come from low density. However, the number of ramifications without capsules observed in low density is nearest of values recorded in medium density (2.20 \pm 1.73 ). Plants with the biggest diameters on collar $(20.67 \pm 5.82)$ have been recorded on low density plots (Table 1).

Table-1: Effect of sowing density on vegetatif parameters of Sesamum indicum

\begin{tabular}{|l|l|l|l|l|l|}
\hline \multirow{2}{*}{ Parameters } & \multicolumn{3}{|c|}{ Sowing densities } & \multicolumn{2}{|c|}{ Statisticals } \\
\cline { 2 - 6 } & Low & Medium & High (control) & $\boldsymbol{F}$ & $\boldsymbol{P}$ \\
\hline RNF & $10.80 \pm 3.12^{\mathrm{a}}$ & $8.18 \pm 2.99^{\mathrm{b}}$ & $7.35 \pm 2.67^{\mathrm{b}}$ & 22.49 & 0.00 \\
\hline RNWF & $8.70 \pm 6.70^{\mathrm{a}}$ & $6.00 \pm 2.21^{\mathrm{b}}$ & $3.86 \pm 1.96^{\mathrm{c}}$ & 26.74 & 0.00 \\
\hline DC (mm) & $2.10 \pm 2.19^{\mathrm{a}}$ & $2.20 \pm 1.73^{\mathrm{ab}}$ & $3.48 \pm 1.81^{\mathrm{b}}$ & 4.49 & 0.01 \\
\hline PSL (m) & $1.39 \pm 0.31^{\mathrm{a}}$ & $1.41 \pm 0.25^{\mathrm{a}}$ & $1.44 \pm 0.26^{\mathrm{a}}$ & 0.57 & 0.56 \\
\hline NDP & $1.33 \pm 0.57^{\mathrm{a}}$ & $2.66 \pm 1.35^{\mathrm{a}}$ & $2.00 \pm 1.04^{\mathrm{a}}$ & 1.28 & 0.34 \\
\hline
\end{tabular}

Ramifications number (RN), ramification number bearing fruits (RNF), ramification number without fruits (RNWF), diameter at collar (DC), plant stem length (PSL), number of dead plants (NDP). F : F-statistical of Fischer et $\boldsymbol{P}:$ Probability associated with test. On the line, each parameter bearing the same letters are statistically similar $(P \geq 0.05)$.

\section{Effect of sowing density on biomass parameters of Sesamum. indicum}

Statistical analysis shows that all parameters of biomass have been influenced by the sowing density $(P \leq 0.05)$. Plants from low density produced more leaf biomass than the two other densities. However, this amount of biomass is nearest to those produced in medium density $(12.31 \pm 1.39)$. It also, plants come from to low density which produced more stem $(21.07 \pm 4.76)$ and root $(5.50 \pm 1.53)$ biomasses. Important quantity of capsule biomasses $(8.80 \pm 7.10)$ has been obtained with plants from medium density than those of the two other densities (Table 2). 
Table-2: Effect of sowing density on biomass parameters of Sesamum indicum

\begin{tabular}{|l|l|l|l|l|l|}
\hline \multirow{2}{*}{ Parameters } & \multicolumn{3}{|c|}{ Sowing densities } & \multicolumn{2}{c|}{ Statisticals } \\
\cline { 2 - 7 } & Low & \multicolumn{1}{|c|}{ Medium } & High (control) & $\boldsymbol{F}$ & $\boldsymbol{P}$ \\
\hline DLB (g) & $17.84 \pm 5.56^{\mathrm{a}}$ & $12.31 \pm 1.39^{\mathrm{ab}}$ & $7.77 \pm 0.56^{\mathrm{b}}$ & 6.88 & 0.02 \\
\hline DCB (g) & $21.07 \pm 4.76^{\mathrm{a}}$ & $17.53 \pm 5.24^{\mathrm{b}}$ & $14.01 \pm 2.43^{\mathrm{c}}$ & 3.99 & 0.02 \\
\hline DSB $(\mathbf{g})$ & $5.50 \pm 1.53^{\mathrm{a}}$ & $2.86 \pm 1.20^{\mathrm{b}}$ & $2.45 \pm 0.11^{\mathrm{b}}$ & 6.42 & 0.03 \\
\hline DRB (g) & $6.66 \pm 3.09^{\mathrm{b}}$ & $8.80 \pm 2.10^{\mathrm{a}}$ & $5.66 \pm 0.65^{\mathrm{b}}$ & 0.038 & 0.04 \\
\hline
\end{tabular}

Dry leaves biomasses (DLB), dry capsules biomasses (DCB), dry stems biomasses (DSB) and dry roots biomasses (DRB); $\boldsymbol{F}$ : F-statistical of Fischer et $\boldsymbol{P}$ : Probability associated with test. On the line, each parameter bearing the same letters are statistically similar $(P \geq 0.05)$.

Effect of sowing density on production parameters of Sesamum indicum

Data recorded in the table 3 indicates that production parameters tested have been influenced by sowing density $(P \leq 0.05)$. Plants from high $(51.66 \pm 4.58)$ and low (51.91 \pm 3.82$)$ sowing densities flower early than come from medium density (53.05 \pm 5.34$)$. It is a same to appearance of the first capsule. Indeed, capsules appear early on plants sown in high $(54.63 \pm 4.58)$ and low $(54.85 \pm 3.74)$ densities than those come from medium density (55.06 \pm 8.34$)$. Concerning capsules number per plant, the sowing from low density recorded the best value $(261.98 \pm 159.03$ capsules/plant $)$ against (201.81 $\pm 131.13 \quad$ capsules/plant) and (120.26 \pm 77.34 capsules/plant) respectively for plants of medium and high densities. Also, plants grown in low density have a better yield $(170.42 \mathrm{~g})$ than those of medium (137.57 g) et high (110.57 g) densities (Table $3)$.

Table-3: Effect of sowing density on production parameters of Sesamum indicum

\begin{tabular}{|l|l|l|l|l|l|}
\hline \multirow{2}{*}{ Parameters } & \multicolumn{3}{|c|}{ Sowing densities } & \multicolumn{2}{l|}{ Statisticals } \\
\cline { 2 - 6 } & Low & Medium & High (control) & $\boldsymbol{F}$ & $\boldsymbol{P}$ \\
\hline DFFE & $51.91 \pm 3.82^{\mathrm{a}}$ & $53.05 \pm 5.34^{\mathrm{b}}$ & $51.66 \pm 4.58^{\mathrm{a}}$ & 4.52 & 0.02 \\
\hline DFCE & $54.85 \pm 3.74^{\mathrm{a}}$ & $55.06 \pm 8.34^{\mathrm{b}}$ & $54.63 \pm 4.58^{\mathrm{a}}$ & 0.08 & 0.92 \\
\hline NCP & $261.98 \pm 159.03^{\mathrm{a}}$ & $201.81 \pm 131.13^{\mathrm{b}}$ & $120.26 \pm 77.34^{\mathrm{c}}$ & 18.78 & 0.00 \\
\hline WS (g) & $170.42 \pm 54.61^{\mathrm{a}}$ & $110.57 \pm 40.61^{\mathrm{c}}$ & $137.57 \pm 49.74^{\mathrm{b}}$ & 6.137 & 0.03 \\
\hline
\end{tabular}

Date of first flower emergenced (DFFE), date of first capsule emergenced (DFCE), number of capsules per plant (NCP), weight of seed per density (WS). $\boldsymbol{F}:$ F-statistical of Fischer et $\boldsymbol{P}$ : Probability associated with test. On the line, each parameter bearing the same letters are statistically similar $(P \geq 0.05)$.

\section{Effect of sowing methods on vegetatif parameters of Sesamum. indicum}

Except stem length, all vegetatif parameters have been influenced by sowing method $(P \leq 0.05)$. Plants grown on flat soil have many branchs $(8.77 \pm 3.27)$ than those from mound soil $(7.95 \pm 3.09)$. Also, plant grown on flat soil have more branchs with fruits $(3.54 \pm 1.96)$ than those from bed $(2.55 \pm 1.85)$. In consequence, plants from flat soil recorded less branchs without capsules. Plants sown on the mound soil have developed the biggest diameter on collar $(28.48 \pm 125.9$ $\mathrm{mm})$. Also, plants grown on bed are very sensitives to fungi attacks $(5.77 \pm 2.29$ dead plants) than those of flat

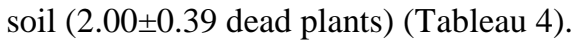

Table-4: Effect of sowing methods on vegetatif parameters of Sesamum. indicum

\begin{tabular}{|l|l|c|c|c|}
\hline \multirow{2}{*}{ Parameters } & \multicolumn{2}{|c|}{ Sowing methods } & \multicolumn{2}{c|}{ Statisticals } \\
\cline { 2 - 5 } & Flat soil (control) & Mound soil & $\boldsymbol{F}$ & $\boldsymbol{P}$ \\
\hline RN & $8.77 \pm 3.27^{\mathrm{a}}$ & $7.95 \pm 3.09^{\mathrm{b}}$ & 5.99 & 0.01 \\
\hline RNF & $7.23 \pm 2.41^{\mathrm{a}}$ & $5.40 \pm 2.24^{\mathrm{b}}$ & 3.46 & 0.04 \\
\hline RNWF & $1.54 \pm 1.96^{\mathrm{a}}$ & $2.55 \pm 1.85^{\mathrm{b}}$ & 24.37 & 0.00 \\
\hline DC (mm) & $17.54 \pm 5.95^{\mathrm{b}}$ & $28.48 \pm 5.99^{\mathrm{a}}$ & 5.35 & 0.02 \\
\hline PSL (m) & $1.41 \pm 0.27^{\mathrm{a}}$ & $1.42 \pm 0.20^{\mathrm{a}}$ & 0.06 & 0.80 \\
\hline NDP & $2.00 \pm 0.39^{\mathrm{b}}$ & $5.77 \pm 2.29^{\mathrm{a}}$ & 5.17 & 0.03 \\
\hline
\end{tabular}

Ramifications number $(\mathbf{R N})$, ramification number bearing fruits (RNF), ramification number without fruits (RNWF), diameter at collar (DC), plant stem length (PSL), number of dead plants (NDP). F : F-statistical of Fischer et $\boldsymbol{P}$ : Probability associated with test. On the line, each parameter bearing the same letters are statistically similar $(P \geq 0.05)$.

\section{Effect of sowing methods on biomass parameters of Sesamum. indicum}

Statistical analysis presented by table 5 show that only capsules biomass has been affected by sowing method on the four parameters tested $(p \leq 0.05)$. In other words, plants from flat soil and mound soil have produced similar value of leaf biomass, stem biomass and root biomass. About capsules biomass the greatest quantity has been produced with plant on mound soil $(17.00 \pm 30.36 \mathrm{~g})$. 
Table-5: Effect of sowing methods biomass parameters of Sesamum. indicum

\begin{tabular}{|l|c|c|c|c|}
\hline \multirow{2}{*}{ Parameters } & \multicolumn{2}{|c|}{ Sowing methods } & \multicolumn{2}{c|}{ Statisticals } \\
\cline { 2 - 5 } & Flat soil (control) & Mound soil & $\boldsymbol{F}$ & $\boldsymbol{P}$ \\
\hline DLB (g) & $12.64 \pm 5.23^{\mathrm{a}}$ & $15.89 \pm 6.32^{\mathrm{a}}$ & 1.40 & 0.25 \\
\hline DCB (g) & $17.54 \pm 4.83^{\mathrm{a}}$ & $16.14 \pm 9.04^{\mathrm{a}}$ & 0.16 & 0.68 \\
\hline DSB(g) & $3.60 \pm 1.73^{\mathrm{a}}$ & $4.31 \pm 1.49^{\mathrm{a}}$ & 0.86 & 0.36 \\
\hline DRB (g) & $7.04 \pm 4.12^{\mathrm{b}}$ & $17.00 \pm 30.36^{\mathrm{a}}$ & 3.95 & 0.03 \\
\hline
\end{tabular}

Dry leaves biomasses (DLB), dry capsules biomasses (DCB), dry stems biomasses (DSB) and dry roots biomasses (DRB) ; $\boldsymbol{F}:$ F-statistical of Fischer et $\boldsymbol{P}:$ Probability associated with test. On the line, each parameter bearing the same letters are statistically $\operatorname{similar}(P \geq 0.05)$.

Effect of sowing methods on production parameters of Sesamum. indicum

Data written in table 6 show that all production parameters tested have been affected by sowing method $(\mathrm{p} \leq 0.05)$. The first flowers $(52.21 \pm 4.63)$ et first capsules $(54.85 \pm 5.87)$ have been observed on plant from soil flat. Plants from bed have produced more capsules on branchs $(205.01 \pm 123.88)$ comparatively to plants from soil flat. It is plants from soil flat which have recorded the best value seed weigh $(139.52 \pm 49.50$ $\left.\mathrm{g} / \mathrm{m}^{2}\right)$.

Table-6: Effect of sowing methods production parameters of Sesamum. indicum

\begin{tabular}{|l|l|l|l|l|}
\hline \multirow{2}{*}{ Parameters } & \multicolumn{2}{|c|}{ Sowing methods } & \multicolumn{2}{c|}{ Statisticals } \\
\cline { 2 - 5 } & Flat soil (control) & \multicolumn{1}{c|}{ Mound soil } & $\boldsymbol{F}$ & $\boldsymbol{P}$ \\
\hline DFFE (Das) & $52.21 \pm 4.63^{\mathrm{a}}$ & $55.07 \pm 4.64^{\mathrm{b}}$ & 34.16 & 0.00 \\
\hline DFCE (Das) & $54.85 \pm 5.87^{\mathrm{a}}$ & $57.96 \pm 4.63^{\mathrm{b}}$ & 31.23 & 0.00 \\
\hline NCP & $194.68 \pm 139.16^{\mathrm{b}}$ & $205.01 \pm 123.88^{\mathrm{a}}$ & 3.55 & 0.04 \\
\hline WS (g) & $139.52 \pm 49.50^{\mathrm{a}}$ & $104.36 \pm 35.81^{\mathrm{b}}$ & 4.98 & 0.00 \\
\hline
\end{tabular}

Date of first flower emergenced (DFFE), date of first capsule emergenced (DFCE), number of capsules per plant (NCP), weight of seed per density (WS). $\boldsymbol{F}:$ F-statistical of Fischer et $\boldsymbol{P}$ : Probability associated with test. On the line, each parameter bearing the same letters are statistically similar $(P \geq 0.05)$.

\section{Effect of block on vegetatif parameters of Sesamum.} indicum

Analysis of table 7 show that only collar diameter and stem length have been affected the block on the five parameters tested $(P \leq 0.05)$. Thus, plants with big diameter have been observed in block 3 $(18.77 \pm 5.74 \mathrm{~mm})$. However, plants of similar diameter have been found in block $2(17.72 \pm 5.97 \mathrm{~mm})$. It is also plants from block 3 which have developed a longer stem (1.52 \pm 0.29$)$ comparatively to those of two blocks.

Table-7: Effect of block methods on vegetatif parameters of Sesamum indicum

\begin{tabular}{|l|l|l|l|l|l|}
\hline \multirow{2}{*}{ Parameters } & \multicolumn{3}{|c|}{ Blocks } & \multicolumn{1}{|c|}{ Statisticals } \\
\cline { 2 - 6 } & \multicolumn{1}{|c|}{ Block 1 } & \multicolumn{1}{|c|}{ Block 2 } & \multicolumn{1}{c|}{ Block3 } & $\boldsymbol{F}$ & $\boldsymbol{P}$ \\
\hline RN & $8.48 \pm 3.76^{\mathrm{a}}$ & $8.66 \pm 2.85^{\mathrm{a}}$ & $9.18 \pm 3.14^{\mathrm{a}}$ & 0.73 & 0.48 \\
\hline RNF & $5.00 \pm 2.68^{\mathrm{a}}$ & $5.01 \pm 2.02^{\mathrm{a}}$ & $5.70 \pm 2.45^{\mathrm{a}}$ & 1.65 & 0.19 \\
\hline RNWF & $3.48 \pm 2.34^{\mathrm{a}}$ & $3.65 \pm 1.87^{\mathrm{a}}$ & $3.50 \pm 1.63^{\mathrm{a}}$ & 0.12 & 0.87 \\
\hline DC (mm) & $16.12 \pm 5.93^{\mathrm{b}}$ & $17.72 \pm 5.97^{\mathrm{ab}}$ & $18.77 \pm 5.74^{\mathrm{a}}$ & 3.10 & 0.04 \\
\hline PSL (m) & $1.30 \pm 0.25^{\mathrm{c}}$ & $1.42 \pm 0.24^{\mathrm{b}}$ & $1.52 \pm 0.29^{\mathrm{a}}$ & 9.62 & 0.00 \\
\hline NDP & $2.66 \pm 1.42^{\mathrm{a}}$ & $2.10 \pm 1.06^{\mathrm{a}}$ & $1.10 \pm 0.21^{\mathrm{a}}$ & 1.28 & 0.34 \\
\hline
\end{tabular}

Ramifications number $(\mathbf{R N})$, ramification number bearing fruits $(\mathbf{R N F})$, ramification number without fruits $(\mathbf{R N W F})$,

diameter at collar (DC), plant stem length (PSL), and number of dead plants (NDP). $\boldsymbol{F}:$ F-statistical of Fischer et $\boldsymbol{P}:$ Probability associated with test. On the line, each parameter bearing the same letters are statistically similar $(P \geq 0.05)$.

Effect of block on biomass parameters of Sesamum. indicum

Analysis of variance shown that biomass parameters have not been affected by block. Indeed, all probabilities associated to four parameters are superior to probability $\mathrm{P}>0.05$ (Table 8 ). 
Table-8: Effect of block methods on biomass parameters of Sesamum. indicum

\begin{tabular}{|l|l|l|l|l|l|}
\hline \multirow{2}{*}{ Parameters } & \multicolumn{3}{|c|}{ Blocks } & \multicolumn{1}{l|}{ Statisticals } \\
\cline { 2 - 6 } & Block 1 & \multicolumn{1}{|c|}{ Block 2 } & Block 3 & $\boldsymbol{F}$ & $\boldsymbol{P}$ \\
\hline DLB (g) & $11.24 \pm 4.30^{\mathrm{a}}$ & $11.52 \pm 2.82^{\mathrm{a}}$ & $15.16 \pm 8.28^{\mathrm{a}}$ & 0.45 & 0.65 \\
\hline DCB (g) & $16.14 \pm 3.45^{\mathrm{a}}$ & $15.94 \pm 1.37^{\mathrm{a}}$ & $20.53 \pm 7.72^{\mathrm{a}}$ & 0.82 & 0.48 \\
\hline DSB(g) & $3.07 \pm 1.23^{\mathrm{a}}$ & $3.89 \pm 2.92^{\mathrm{a}}$ & $3.84 \pm 1.14^{\mathrm{a}}$ & 0.16 & 0.85 \\
\hline DRB (g) & $5.40 \pm 1.28^{\mathrm{a}}$ & $5.13 \pm 1.31^{\mathrm{a}}$ & $10.59 \pm 6.03^{\mathrm{a}}$ & 2.13 & 0.19 \\
\hline
\end{tabular}

Dry leaves biomasses (DLB), dry capsules biomasses (DCB), dry stems biomasses (DSB) and dry roots biomasses (DRB) ; $\boldsymbol{F}:$ F-statistical of Fischer et $\boldsymbol{P}:$ Probability associated with test. On the line, each parameter bearing the same letters are statistically similar $(P \geq 0.05)$

\section{Effect of block on production parameters of Sesamum. indicum}

All production parameters tested have been significatively affected by block $(P \leq 0.05)$. Thus, it with block 3 first flowers $(50.33 \pm 4.05)$ and capsules $(53.31 \pm 4.06)$ have been observed. At the same period some plants from block 2 produced capsules $(55.11 \pm 4.19)$. It plants from block $2(202.55 \pm 150.66)$ and block $3(236.71 \pm 143.81)$ which produced more capsules. But plants of block 3 recorded the best value of seed weight $(186.05 \pm 42.69 \mathrm{~g})$ (Tableau 9).

Table-9: Effect of block methods on production parameters of Sesamum. indicum

\begin{tabular}{|c|c|c|c|c|c|}
\hline \multirow[t]{2}{*}{ Parameters } & \multicolumn{2}{|c|}{ Blocks } & & \multicolumn{2}{|c|}{ Statisticals } \\
\hline & Block 1 & Block 2 & Block 3 & $F$ & $P$ \\
\hline DFFE (Das) & $54.21 \pm 4.87^{\mathrm{c}}$ & $52.08 \pm 4.17^{b}$ & $50.33 \pm 4.05^{\mathrm{a}}$ & 11.82 & 0.00 \\
\hline DFCE (Das) & $56.11 \pm 8.15^{b}$ & $55.11 \pm 4.19^{\mathrm{ab}}$ & $53.31 \pm 4.06^{\mathrm{a}}$ & 4.60 & 0.02 \\
\hline NCP & $144.80 \pm 104.81^{b}$ & $202.55 \pm 150.66^{a}$ & $236.71 \pm 143.81^{\mathrm{a}}$ & 7.14 & 0.00 \\
\hline WS (g) & $109.24 \pm 26.48^{\mathrm{c}}$ & $123.27 \pm 47.53^{\mathrm{b}}$ & $186.05 \pm 42.69^{\mathrm{a}}$ & 4.14 & 0.01 \\
\hline
\end{tabular}

Date of first flower emergenced (DFFE), date of first capsule emergenced (DFCE), number of capsules per plant (NCP),

weight of seed per density (WS). $\boldsymbol{F}:$ F-statistical of Fischer et $\boldsymbol{P}$ : Probability associated with test. On the line, each parameter bearing the same letters are statistically similar $(P \geq 0.05)$

\section{DISCUSSION}

Determination of optimium density constitutes an important step to increase production of any crops [8, 9]. In this context, a present study has been undertaken to improve the growing system and increase sesame production. It results for investigations that sesame plants sown on the plots with low density recorded the best value of yield and its components. A low density is characterized by a population with a few individuals on a unity of surface. What means an absence of competition for space, water, light and nutrients [10]. Availability of nutrients in quality for plants allows them to carry out their function physiological and reproduction which is contributed probabily to record a result. Similar results have been recorded by Valiki et al.[11], studing the same crops. Those authors explained their results by the availability of environment resources. This opinion, has been noted by Taffouo et al. [12] determining optimium density of Vigna unguiculata L., Walp.

In addition, results from the current study shown that plants realized on flat soil recorded the best value of yield and its components than plants from mound soil. Earthing up consist to break up soil in order to allow plants take roots easily. This way of growing is frequently used for tuber crops and those with pod mainly yam, sweet potato, groundnut and others[13]. Because of climate change or disturbance of rainy regime this practice spreads progressively to others crops todays. A trial has been taken during the dry season particularly December, January, February and March which obliged experimenter to water plants each three days. In this condition, frequency and excess of water brought to plants could explain this result. This opinion is supported by[14]. Indeed, the fast water seepage and its difficult flow on mound soil favoured a damp environment around plants. Sesame is tropical crop and indicated by several authors as very sensitive to water excess. Thus, soil humidity has probably favoured diseases proliferation. During experimentation a death number of plants due to fungi infection have been observed on the plot with mound soil. On farm observations agree with results of Romain et al. [15]. According to them, heavy rain or soil very humid lead to proliferation of pathogens mainly sesame fungi which attack stems, leaves and capsules which provoke a decrease of yield.

Our results also shown that yield and its components have not been influenced by the blocks. That could be justified by soil homogeneity with nutritious. Indeed, experiment site had previously used to grow together several crops such as maize, tomato, okra and soybean. Thus, after harvest, crops waste decomposition by soil microorganism had probably contributed to soil restoration in minerals. In addition, soybean is a leguminous plant fixative of nitrogen which could also justified the homogeneity of the soil. Indeed, according to Teame et al.[16] the provision of organic matter in the soil improve fertility level which favoured development and productivity of crops. 


\section{CONCLUSION}

It emerges from this study that a production of sesame is affected by sowing density and sowing method. Concerning the first production factor, the best value of yield come from plants grown on plot with low density. With second factor, the highest value of yield has been recorded with sowing on flat soil. Base on this result it has been recommended to sesame producers to grow this crop on flat soil with a low density.

\section{REFERENCES}

1. Sanogo S. Le sésame: une opportunité pour la diversification de la production agricole. Mémoire de master, Université de Ouagadougou, Burkina Faso, 2008; 61.

2. Goossens F. Aliments dans les villes: Rôle des SADA dans la sécurité alimentaire de Kinshasa. Canada, FAO.1997; 75.

3. Andres L and Lebailly P. Le sésame dans le département d'Aguié au Niger : analyse d'une culture aux atouts non-négligeables dans une zone agricole à forte potentialité. Tropicultura. 2013; 31(4): 38-246.

4. Haruna $\mathbf{M}$ and Abimiku MS. Yield of Sesame (Sesamum indicum L.) as Influenced by organic fertilizers in the southern Guinea savanna of Nigeria. Sustainable Agriculture Research. 2012;1(1): 66-69.

5. Noorka IR, Hafiz SI and El-Bramay MAS. Response of sesame to population densities and nitrogen fertilization on newly reclaimed sandy soils. Pakistan Journal of Botanic, 2011;43(4): 1953-1958.

6. Ngala AL, Dugje IY and Yakubu H. Effects of inter-row spacing and plant density on performance of sesame (Sesamum indicum L.) in a Nigerian sudan savanna. International Sciences, 2013; 25(3): 513-519.

7. koffie-bikpo CY and Kra KS. La région du HautSassandra dans la distribution des produits vivriers agricoles. Rapport Instut de Géographie Tropical, Côte d'Ivoire. 2013; 8.
8. Olowe VIO and Busari LD. Growth and grain yield of two sesame (Sesamum indicum L.) varieties as affected by row spacing in southern Guinea savanna of Nigeria. Samaru Journal of Agriculture Research, 2003;19: 91-101.

9. Dorval D. Effet du cultivar et de la densité de semis sur la productivité et la qualité des grains de l'épeautre de printemps et d'automne. Mémoire de maîtrise, Université LAVAL (Québec, Canada). 2015; 96

10. El Naim AM, El Day EM and Ahmed AA. Effect of plant density on the performance of some sesame (Sesamum indicum L) cultivars under rain fed. Research Journal of Agriculture and Biological Sciences. 2010;6(4): 498-504.

11. Valiki SRH, Ghanbari S, Golmohammadzadeh S and Kiasari KR. Effect of different plant density on growth and yield of three cultivars of sesame (Sesamum indicum L.) Biological Forum. 2015;7: 1524-1528.

12. Taffouo DT, Etamé J, Din N, Nguelemeni MLP, Eyambé YM, Tayou RF and Akoa A. Effets de la densité de semis sur la croissance, le rendement et les teneurs en composés organiques chez cinq variétés de niébé (Vigna unguiculata L. Walp). Journal of Applied Biosciences. 2008;12: 623 - 632.

13. La France D and Maynard E. Les engrais verts en culture maraîchère. Conseil pour le developpement de l'agriculture du Québec (CDAQ), Longueuil, Canada. 2007; 8.

14. El Mahdi AR, El-Amin SE. Effect of irrigation intervals on growth and yield of sesame (Sesamum indicum L.) in Northern Sudan. Assiut Journal of Agricultural Science. 2008;39(1):1-9.

15. Romain HR. Le sesame (Sesamum indicum L) en « Agriculture en Afrique Tropicale ». Centre d'etude régional pour l'amélioration de l'adaptation à la sécheresse (CERAAS), Sénégal. 2001;1634.

16. Teame G, Tsegay A and Abrha B. Effect of organic mulching on soil moisture, yield, and yield contributing components of sesame (Sesamum indicum L.). International Journal of Agronomy. 2017: $1-6$ 